\title{
Laying performance, digestibility and plasma hormones in laying hens exposed to chronic heat stress as affected by betaine, vitamin $\mathrm{C}$, and/or vitamin $\mathrm{E}$ supplementation
}

\author{
Youssef A. Attia 1* Abd El-Hamid E. Abd El-Hamid², Ahmed A. Abedalla ${ }^{3}$, Marfat A. Berika ${ }^{3}$, \\ Mohammed A. Al-Harthi ${ }^{1}$, Osman Kucuk ${ }^{4}$, Kazim Sahin ${ }^{5}$ and Baha M. Abou-Shehema ${ }^{3}$
}

\begin{abstract}
Heat stress had a negative effect on laying hens' performance, thus this research was to study the influences of betaine (Bet, $1000 \mathrm{mg} / \mathrm{kg}$ betaine), vitamin C (VC, $200 \mathrm{mg} / \mathrm{kg}$ ascorbic acid), and vitamin E (VE, $150 \mathrm{mg} / \mathrm{kg}$ a-Tocopherol acetate) and their possible combinations on egg production, digestibility of nutrients, plasma hormones and reproductive organs of dual-purpose hens exposed to chronic heat stress. Two hundred and eighty eight hens and thirty-six cocks from 32 to 48 weeks of age were divided into nine treatment groups of four replicates, each containing eight hens and one cock. One group was kept under thermo-natural condition and the eight others were kept under chronic heat stress (CHS). One of these eight was used as a negative control, while the others were supplemented with VC, VE and/or betaine and their possible combinations. Body weights, laying rate, feed intake, and feed conversion ratio in hens reared under CHS rooster without any supplementation during 32 to 48 weeks of impairment $(P=0.0052)$ were recorded. Hens reared under heat stress and fed a diet supplemented with either Bet, VC, VE or combination of the supplements increased production traits. However, hens supplemented with VC showed the greatest production traits. Plasma glucose, estradiol-17 $\left(E_{2}\right)$, progesterone $\left(P_{4}\right)$, tri-iodothyronine $\left(T_{3}\right)$ and thyroxine $\left(\mathrm{T}_{4}\right)$ decreased in hens reared under CHS and fed a diet with no supplementation compared to the other treatments $(P=0.001)$. Liver weights, spleen weights, thyroid gland weights, ovary weights, oviduct weights and oviduct lengths were lowest in hens reared under CHS and fed a diet with no supplementation $(P=0.0480)$. In conclusion, dual purpose hens reared under CHS and supplemented with VC at $200 \mathrm{mg} / \mathrm{kg}$ diet and Bet at $1000 \mathrm{mg} / \mathrm{kg}$ enhanced the laying performance and combated CHS.
\end{abstract}

Keywords: Laying hens, Performance, Heat stress, Betaine, Vitamin C, Vitamin E

\section{Background}

In the tropic, heat stress (HS) are most important factor that negatively affects animal performance. Heat stress adversely influences feed intake, reproductive and laying performance, economical traits and decrease welfare of laying hens (Daghir 2008). High temperature negatively

\footnotetext{
*Correspondence: yaattia@kau.edu.sa

${ }^{1}$ Arid Land Agriculture Department, Faculty of Meteorology, Environment and Arid Land Agriculture, King Abdulaziz University, P.O. Box 80208, Jeddah 21589, Saudi Arabia

Full list of author information is available at the end of the article
}

affect feed intake and consequently endocrine system, acid-base imbalance and organs' functions. These adverse influences the process of egg formation at levels ovary and reproductive tract as well as process of ovulation and oviposition (Rozenboim et al. 2007; Oguntunji and Alabi 2010). Both environmental temperature and relative humidity interacted to affect HS severity (Attia et al. 2006; Tumová and Gous 2012), and laying hens strain (Franco-Jimenez et al. 2007). Vitamin C and vitamin $\mathrm{E}$ as antioxidant and trimethylglycine (Betaine; Bet) has been suggested to alleviate the adverse effects on HS on laying hens (Daghir 2008; Attia et al. 2009, 2011). 
Betaine or Trimethylglycine and implicated in biological process such as, osmoprotective, methionine and choline sparing, fat distribution and immunity (Graham 2002). However, animal feedstuffs are poor supply for Bet and supplementation appears essential for enhancing performance and stress resistance in poultry (Wang et al. 2004). Bet has been reported to improve growth, carcass yields and muscle protein deposition in broilers (Türker et al. 2004) and in ducks (Wang et al. 2004) and reduce fat (Attia et al. 2005; Hassan et al. 2005).

Vitamin $C$ is a water-soluble vitamin with anti-oxidant activity, protecting animals under stress (Attia et al. 2009). Vitamin $C$ is essential for collagen, 1, 25-dihydroxy vitamin $\mathrm{D}$ and biosynthesis of adrenaline and corticosterones secretion, body temperature regulation and boosting immunity (Panda et al. 2008). Vitamin C supplementation was found to alleviate the negative effect of stress on metabolic process and enhances production, and boosts immunity (Daghir 2008; Attia et al. 2009; Khan et al. 2012a). Feed intake, survivability, feed intake and laying characteristics of layers were found to be enhanced by vitamin C supplementation at $200-400 \mathrm{mg} /$ kg (Daghir 2008; Çiftçi et al. 2005).

Vitamin E plays a crucial role in cell-protection and free radicals scavengers (Bollengier-Lee et al. 1999; Metwally 2003; Khan et al. 2011). Catecholamines and coticosterone release and lipid peroxidation in cell membranes are initiated by heat stress. Vitamin E requirements must be supplied in order to compact heat stress. Metwally (2003) suggested that vitamin $\mathrm{E}$ could decrease the adverse influences of corticosterone induced by stress. Vitamin $\mathrm{E}$ also protects lymphocytes, macrophages and plasma cells against oxidative damage and enhances immune cell functions and proliferations (Traber 2007; Khan et al. 2012b). Hence, dietary vitamin E supplementation is essential under conditions of HS. The objective of this research was to study the influences of betaine, vitamin C and vitamin $\mathrm{E}$ alone or as a combination supplemented to the diet of dual-purpose hens under chronic heat stress on performance, egg yield, nutrients' digestibility, plasma hormones and organ weights.

\section{Methods}

The experimental protocol of this study was approved by Animal Production Research Institute Scientific and Ethical committee under registration no. 1037, code no. 01100337 approval date July 11, 2010.

\section{Laying hens, design, housing and diets}

A total of 288 hens and 36 roosters of Mandarah strain (a native breeders classified as a dual-purpose hens). The experiment was started at 32 and terminated at 48 weeks of age. Birds were housed in an environmental-controlled lightproof house (close system-controlled for temperature, humidity and light). Chickens were divided into nine treatment groups with equal numbers in straight run experimental design. Hens were housed in 36 floor pens $(2 \mathrm{~m} \times 1.2 \mathrm{~m} \times 2 \mathrm{~m})$ furnished with wheat straw. Each treatment was replicated 4 times, each containing 8 hens and 1 cock. The birds were reared either at an optimum temperature of $22-24{ }^{\circ} \mathrm{C}$ with relative humidity (RH) of $45-55 \%$ serving as positive control (T1) and fed with a basal diet (Table 1$)$ or under $\mathrm{CHS}\left(38^{\circ} \mathrm{C} \pm 1\right.$; $55-65 \% \mathrm{RH}$ ) for three successive days a week from 11.00 a.m. to 15.00 p.m. Optimal temperature $\left(22-24{ }^{\circ} \mathrm{C}\right)$ in the hen house was maintained using cool-cell-pads. Under normal condition, the relative humidity was adjusted automatically (ranged between 45 and $55 \%$ ). The air is removed from the house by means of exhaust fans; fresh air is allowed to enter through the cool-cell-pads openings. Chickens under CHS were divided into eight groups, i.e., chickens kept under $\mathrm{CHS}$ and fed with a basal diet serving as negative control (T2); chickens kept under $\mathrm{CHS}$ and fed with a basal diet supplemented with

Table 1 Ingredients and composition of the experimental diet (as fed basis) fed to laying hens

\begin{tabular}{|c|c|}
\hline Ingredients and composition & $\mathrm{g} / \mathrm{kg}$ \\
\hline Yellow corn, ground & 663.3 \\
\hline Soybean meal 48 \% CP & 242.0 \\
\hline Limestone & 75.0 \\
\hline Dicalcium phosphate & 13.2 \\
\hline Vit + Min Premix ${ }^{a}$ & 2.5 \\
\hline $\mathrm{NaCl}$ & 2.5 \\
\hline DL-methionine & 1.5 \\
\hline \multicolumn{2}{|c|}{ Calculated and determined composition } \\
\hline $\mathrm{ME}, \mathrm{MJ} / \mathrm{kg}^{\mathrm{b}}$ & 11.62 \\
\hline Dry matter, g/kg & 907.3 \\
\hline $\mathrm{CP}, \mathrm{g} / \mathrm{kg}^{\mathrm{c}}$ & 170.6 \\
\hline Ether extract, $\mathrm{g} / \mathrm{kg}^{\mathrm{c}}$ & 24.5 \\
\hline Crude fibre, $\mathrm{g} / \mathrm{kg}^{\mathrm{c}}$ & 39.6 \\
\hline Methionine, $\mathrm{g} / \mathrm{kg}^{\mathrm{b}}$ & 3.91 \\
\hline Ash, $\mathrm{g} / \mathrm{kg}^{\mathrm{c}}$ & 63.7 \\
\hline Nitrogen free extract, g/kg & 609.8 \\
\hline Meth. + Cys. (TSAA, g/kg) & 6.7 \\
\hline Lysine, $\mathrm{g} / \mathrm{kg}^{\mathrm{b}}$ & 8 \\
\hline Calcium, $\mathrm{g} / \mathrm{kg}^{\mathrm{b}}$ & 31 \\
\hline Available $P, \mathrm{~g} / \mathrm{kg}^{\mathrm{b}}$ & 3.74 \\
\hline \multicolumn{2}{|c|}{$\begin{array}{l}\text { ait + Min mixture provides per kilogram of diet: vitamin } \mathrm{A}, 12,000 \mathrm{IU} \text {; vitamin } \\
\mathrm{E}, 10 \mathrm{IU} \text {; menadione, } 3 \mathrm{mg} \text {; Vit. } \mathrm{D}_{3}, 2200 \mathrm{ICU} \text {; riboflavin, } 10 \mathrm{mg} \text {; Ca pantothenate, } \\
10 \mathrm{mg} \text {; nicotinic acid, } 20 \mathrm{mg} \text {; choline chloride, } 500 \mathrm{mg} \text {; vitamin } \mathrm{B}_{12}, 10 \mathrm{~g} \text {; vitamin } \\
\mathrm{B}_{6}, 1.5 \mathrm{mg} \text {; vitamin } \mathrm{B}_{1}, 2.2 \mathrm{mg} \text {; folic acid, } 1 \mathrm{mg} \text {; biotin, } 50 \mathrm{~g} \text {. Trace mineral } \\
\text { (milligrams per kilogram of diet): } \mathrm{Mn}, 55 ; \mathrm{Zn}, 50 ; \mathrm{Fe}, 30 ; \mathrm{Cu}, 10 ; \mathrm{Se}, 0.10 ; \text { Anti } \\
\text { oxidant, } 3 \mathrm{mg}\end{array}$} \\
\hline \multicolumn{2}{|c|}{ b Calculated from NRC (1994) table values } \\
\hline c Deterimed values based on AOAC & \\
\hline
\end{tabular}


$1000 \mathrm{mg} / \mathrm{kg}$ betaine (T3) (natural Betafin ${ }^{\circledR}$ S4 contain 93 \% dry Bet, Danisco Animal Nutrition, UK); chickens kept under CHS and fed with a basal diet supplemented with $200 \mathrm{mg} / \mathrm{kg}$ ascorbic acid (T4) (L-ascorbic acid; a heat stabilized product, Hoffmann-La Roche, Switzerland); chickens kept under CHS and fed with a basal diet supplemented with $150 \mathrm{mg} / \mathrm{kg} \alpha$-Tocopherol acetate (T5) ( $\alpha$-Tocopherol acetate, Hoffmann-La Roche, Switzerland); chickens kept under CHS and fed with a basal diet supplemented with $1000 \mathrm{mg} / \mathrm{kg}$ betaine and $200 \mathrm{mg} /$ $\mathrm{kg}$ ascorbic acid (T6); chickens kept under CHS and fed with a basal diet supplemented with $1000 \mathrm{mg} / \mathrm{kg}$ betaine and $150 \mathrm{mg} / \mathrm{kg} \alpha$-Tocopherol acetate (T7); chickens kept under $\mathrm{CHS}$ and fed with a basal diet supplemented with $200 \mathrm{mg} / \mathrm{kg}$ ascorbic acid and $150 \mathrm{mg} / \mathrm{kg} \alpha$-Tocopherol acetate (T8) or chickens kept under CHS and fed with a basal diet supplemented with $1000 \mathrm{mg} / \mathrm{kg}$ betaine, $200 \mathrm{mg} / \mathrm{kg}$ ascorbic acid, and $150 \mathrm{mg} / \mathrm{kg} \alpha$-Tocopherol acetate (T9).

Feeds and water were provided ad libitum throughout the experimental period. Vaccination and medical program were done according to common veterinarian care practice. Chickens were provided with $16 \mathrm{~h}$ light $-8 \mathrm{~h}$ dark cycles using automatic timers to schedule the lighting regimens.

\section{Measurements \\ Laying performance}

Laying rate (egg number/hen/d), egg weight (g), egg mass $(\mathrm{g} / \mathrm{hen} /$ day $)$ and feed intake $(\mathrm{g} / \mathrm{hen} / \mathrm{d})$ were recorded daily for each replicate. Feed conversion ratio (FCR) was calculated as the amount of feed consumed $(\mathrm{g})$ required to produce a unit $(\mathrm{g}$ ) of egg mass (feed conversion $=\mathrm{g}$ feed/g egg). Feed conversion ratio was predicated every 4 weeks throughout the experimental period. Mortality rate was recorded during the experimental period, and post-mortem investigation was done by veterinarians. The data from mortality rate was utilized to estimate the survival rate.

\section{Digestibility of nutrients}

Four roosters at 48 weeks of age from each treatment (as four replicates of one male) were used to determine the digestibility coefficient values namely, dry matter (DM), crude protein (CP), ether extract (EE), crude fiber (CF) and nitrogen free extract (NFE) using the method described by Attia et al. (2012). Roosters were fasted for $24 \mathrm{~h}$ and then fed with their corresponding experimental diets for $72 \mathrm{~h}$ followed by collection of excreta. The excreta was collected for each replicate, cleaned from feeds and feathers, and then weighed, dried in a forced air oven at $70{ }^{\circ} \mathrm{C}$ for $36 \mathrm{~h}$. Samples were then finally ground and placed in screw-top glass jars until analyses.
Excreta nitrogen was measured using procedures outlined by Jakobsen et al. (1960). The proximate analysis of diet and excreta were done according to Association of official Analytical Chemists AOAC (2004). Coefficient of nutrient digestibility were calculated according to Attia et al. (2012).

\section{Blood analyses}

At 48 weeks of age, $5 \mathrm{ml}$ blood samples were withdrawn from the brachial vein from two hens per replicate per treatment. Blood samples were collected in the morning from the overnight-fasted chickens. Each sample was collected in two tubs; one without anticoagulant, while in the other, heparin was used as an anticoagulant. Plasma and serum was obtained by centrifugation of blood at $1500 \times g$ for $20 \mathrm{~min}$ and kept at $-20^{\circ} \mathrm{C}$ until used for analysis. Plasma glucose $(\mathrm{mg} / \mathrm{dl})$ was measured by the method of Trinder (1969) using diagnostic kits (Diamoned Diagnstics, USA). Concentrations of plasma estradiol-17 $\left(\mathrm{E}_{2}\right)$ and progesterone $\left(\mathrm{P}_{4}\right)$ were assayed via radioimmunoassay (RIA) using DSL-43100 and DSL3900, respectively (Diagnostic systems Laboratories Inc, TX, USA) according to the method described by Abraham (1977). Plasma triiodothyronine $\left(\mathrm{T}_{3}\right)$ was analyzed using radioimmunoassay (RIA) kits (Diagnostic Systems Laboratories USA by Automatic 1275 mini Gamma Counter LKB) according to the method described by Hollander and Shenkman (1974).

Slaughter test At 48 weeks of age, two hens per replicate per treatment were individually weighed and slaughtered; body organ measurements were calculated as a percentage of live body weight. Ovary, oviduct, total ovarian follicle, large yellow follicle; small white follicle were removed immediately, and then weighted separately to the nearest gram. The weights of these organs were expressed as the percentage of live weight.

Statistical analysis Data were analysed using the GLM procedure of Statistical Analyses Software ${ }^{\circledR}$ (SAS 1996) using one-way ANOVA according to the following model: yij $=\mu+\tau j+\varepsilon i j$, where $\mu=$ the general mean, $\tau j=$ the effect of treatment, $\varepsilon \mathrm{ij}=$ the experimental error. Before analysis, all percentages were converted to arcsine to normalize data distribution. Mean difference at $P=0.05$ was tested using student Newman Kelus test.

\section{Results}

As planned, the initial body weights remained similar among the treatments $(P=1.00)$ (Table 2). However, body weight changes in hens reared under $\mathrm{CHS}$ without any supplementation during 32-48 weeks were the lowest $(P=0.001)$. Survival rate also followed similar pattern 


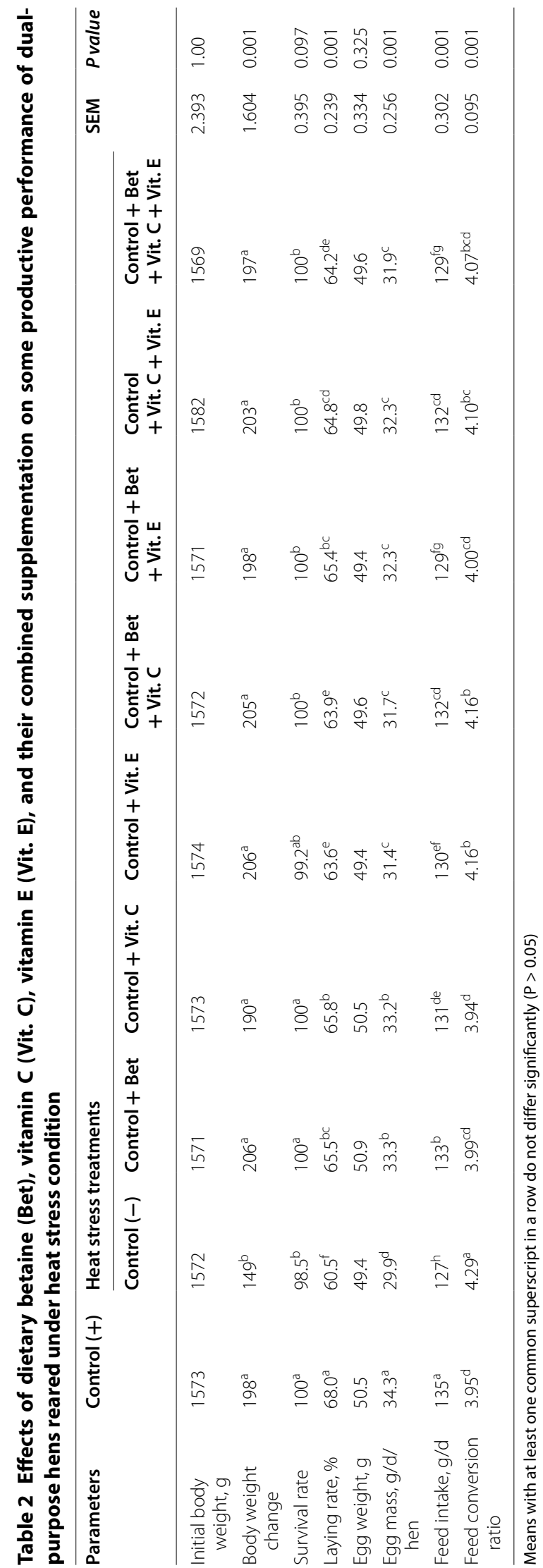


to the body weight changes. Laying rate was greatest in hens reared under optimum thermal conditions (no heat stress); hens reared under CHS without any supplementation had lowest laying rate $(P=0.001)$. Hens reared under $\mathrm{CHS}$ but fed a diet supplemented with either Bet, VC, VE or combination of these supplements increased laying rate, hens supplemented with $\mathrm{VC}$ being greatest. Egg weights did not change among treatments $(P=0.325)$. However, egg masses were greatest in hens reared under optimum thermal conditions, and hens reared under CHS without any supplementation had lowest egg masses $(P=0.001)$. Hens reared under $\mathrm{CHS}$ but fed a diet supplemented with either Bet, VC, VE or combination of these supplements increased rate of laying, hens supplemented with Bet and vitamin $\mathrm{C}$ being greatest.

Feed intake was greatest in hens reared under optimum thermal conditions, and hens reared under CHS without any supplementation had lowest feed intake $(P=0.001)$. Hens reared under CHS but fed a diet supplemented with either Bet, VC, VE or combination of these supplements increased feed intake, hens supplemented with VC being greatest. Hens reared under thermal conditions and hens reared under CHS and fed a diet supplemented with VC had greatest FCR compared with hens reared under $\mathrm{CHS}$ with or without supplementation $(P=0.001)$. Hens fed a diet with no supplementation had the worst FCR.

Nutrient digestibility of DM, EE, CF and NEF remained similar in hens reared either optimal thermal conditions or under CHS (Table 3). Digestibility of CP was greatest in hens reared at thermal conditions compared with hens reared under CHS with hens fed a diet supplemented with Bet, VC and VE together $(P=0.001)$ were intermediate. Digestibility of CP was most negatively influenced in hens reared under CHS and fed a diet with no supplementation at all.

Plasma glucose concentrations were lowest in hens reared under $\mathrm{CHS}$ and fed a diet with no supplementation, and were similar all the other treatments $(P=0.001)$ (Table 4). Concentrations of serum estradiol-17 $\left(E_{2}\right)$ were lowest in hens reared under CHS and fed a diet with no supplementation, were greatest in hens reared at thermal conditions, and were similar all the other treatments $(P=0.001)$. Concentrations of serum progesterone $\left(P_{4}\right)$ were lowest in hens reared under $\mathrm{CHS}$ and fed a diet with no supplementation, and were greatest in hens reared at optimal thermal conditions $(P=0.001)$. Responses in plasma $T_{3}$ and $T_{4}$ concentrations were similar among the treatments in such a way that hens reared under CHS and fed a diet with no supplementation had lowest concentrations of $\mathrm{T}_{3}$ and $\mathrm{T}_{4}$, and hens in all other treatments were similar $(P=0.006)$. The ratio of $\mathrm{T}_{3}$ to $\mathrm{T}_{4}$ remained similar among treatments $(P=1.000)$. Although the abdominal fat was similar among treatments $(P=0.151)$, dressing percentages, liver weights, spleen weights, thyroid gland weights, ovary weights, oviduct weights and oviduct lengths were the lowest in hens reared under $\mathrm{CHS}$ and fed a diet with no supplementation $(P=0.048)$ (Table 5).

\section{Discussion}

Layers are susceptible to heat stress due to their high metabolic heat production caused by increasing egg formation (Blem 2000). In addition, convection and radiation displayed a little heat dissipation in hens due to very effective insulation of the body surface by their feather. The lack of sweat glands and low respiratory water evaporation limit the ability to hens to maintain normal temperature during heat stress (Dawson and Whittow 2000). The optimal ambient temperature for laying hens is about $20-25^{\circ} \mathrm{C}$ (Daghir 2008; Tumová and Gous 2012). Heat stress induced adverse effects on layers when temperature exceed $30{ }^{\circ} \mathrm{C}$ (Bollengier-lee et al. 1999; Attia et al. 2006), negatively influencing intake of nutrients and laying characteristics (Attia et al. 2006, 2009, 2011; Daghir 2008) as shown in the present work. In the case of the adverse influences of the heat stress of the present work, the first main issue is the survival rate. Hens reared under CHS and fed a diet with no supplementation had lower $(1.5 \%)$ survival rate and post-mortem investigation showed hens died of heat stress; exhibited a sign of heat stress such as lungs, liver and ovary haemorrhage and emphysema. High environmental temperatures causing heat stress in poultry result in stressful behavioural responses such as panting, elevated respiratory rate, and consequently dehydration, which may cause death due to heat stroke (Ayo et al. 2010). If timely intervention measures are adopted, birds may be salvaged from death, although a high rate $(3.7 \%)$ of culled birds due to heat stress has been reported during the hot-dry season in Nigeria (Ayo et al. 2010). Abd-Ellah (1995) reported $28 \%$ increase in mortality rate in laying hens reared in arid weather conditions of Egypt. The difference in the two reported values (Ayo et al. 2010; Abd-Ellah 1995) is probably due to the greater severity of heat stress in arid conditions of Egypt, with an ambient temperature of about $43^{\circ} \mathrm{C}$.

Further evidence of negative effects of the CHS in the present work was the decreases in body weight changes ( $2.5 \%)$, laying rate $(11 \%)$, egg mass $(12.8 \%)$, feed intake $(5.9 \%)$ and FCR $(8.6 \%)$ in hens reared under $\mathrm{CHS}$ and fed a diet with no supplementation. Decreasing feed intake is one of the major responses of laying hens in order to maintain homoeothermic and minimize heat production (Yousef 1985). The poor productive performance is mainly due to the reduction in feed consumption, which leads to less protein biosynthesis and/or less 


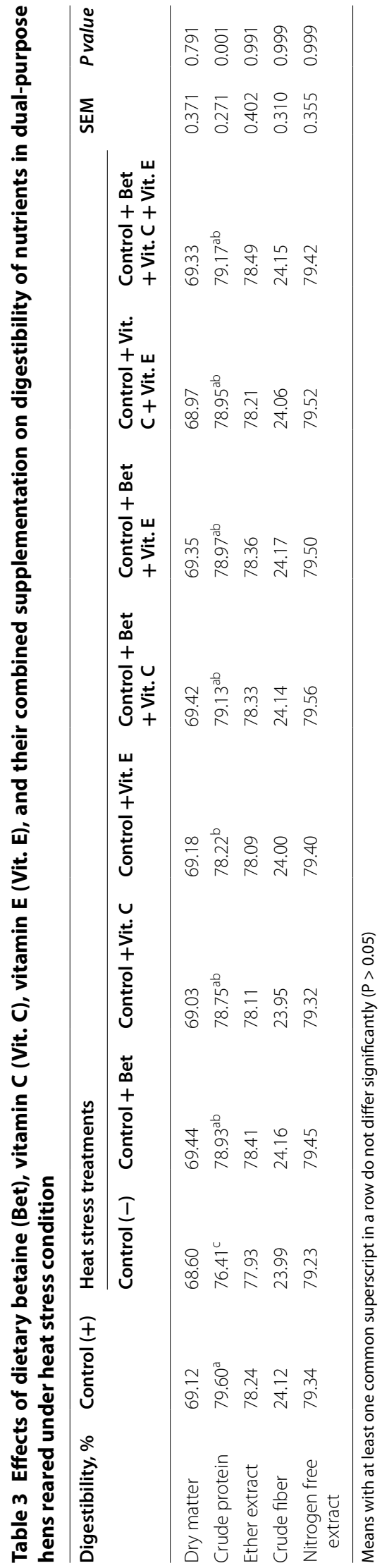




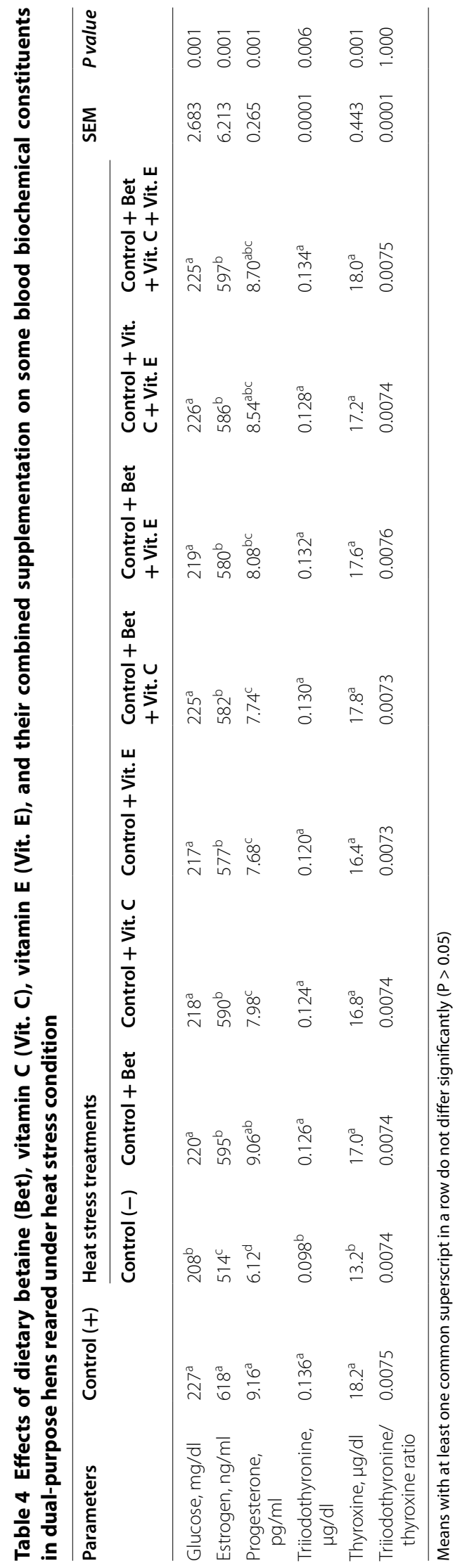




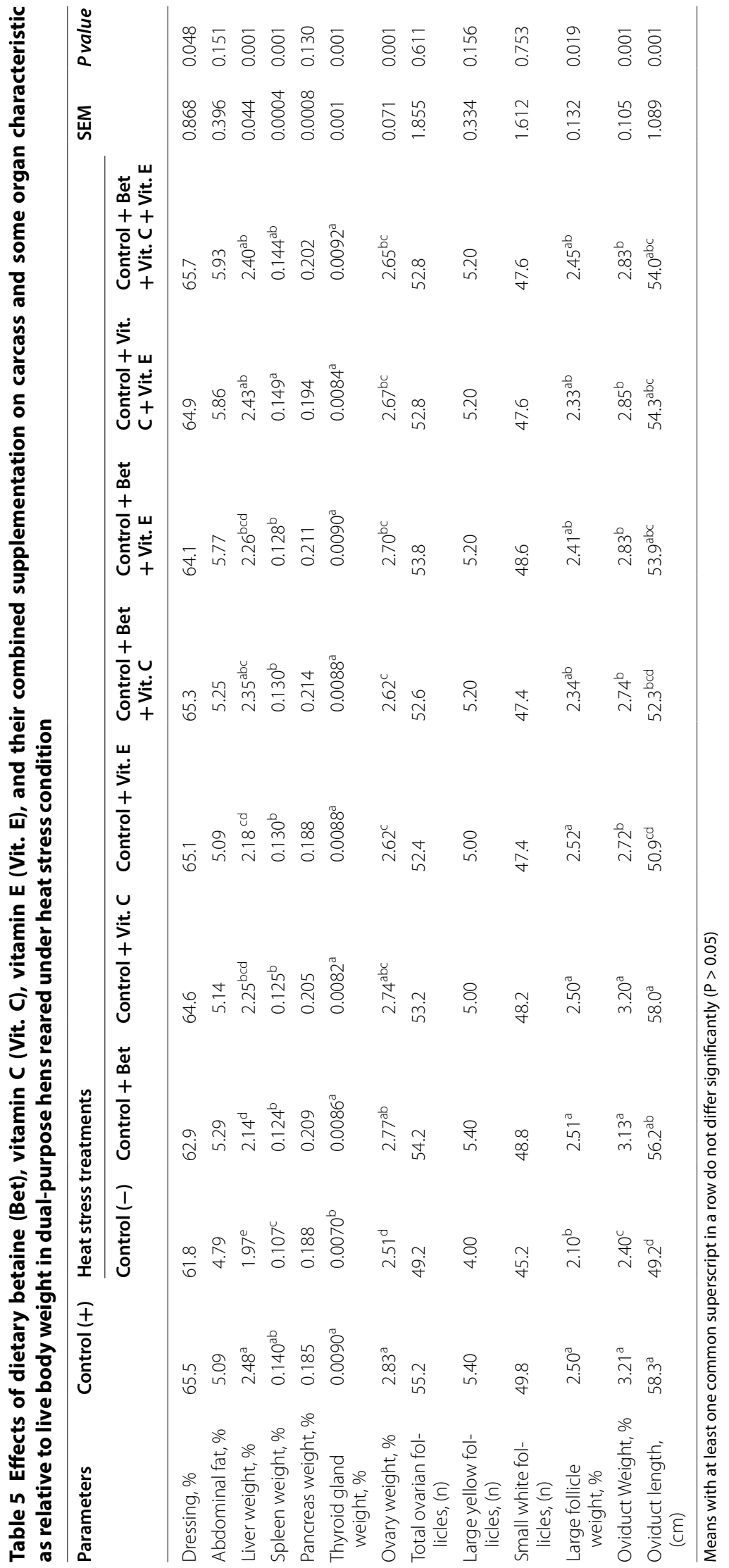


fat deposition (Yousef 1985). Plasma concentrations of $\mathrm{T}_{3}$ are highly correlated to feed intake and ambient temperature in birds (Yahav et al. 1995). As observed in the present study, plasma $\mathrm{T}_{3}$ levels drop instantly after exposure to heat stress in birds presumably in order to decrease heat production and sustain homoeothermic (Uni et al. 2001). These results reveal that the reduced feed consumption indicated in heat stressed chickens may also be as a result of the thermally-induced changes in plasma $\mathrm{T}_{3}$ levels. In the present study, breeders exposed to CHS significantly decreased plasma $\mathrm{E}_{2}, \mathrm{P}_{4}, \mathrm{~T}_{3}$ and $\mathrm{T}_{4}$, showing impairment in the ovarian and thyroid functions.

Further evidence of the negative effect of CHS was recorded on body weight gain that showed a $24.7 \%$ reduction in hens reared under CHS. These results correlate with the result reported by Smith (1994) who concluded that exposure to high ambient temperatures and high relative humidity altered respiration and other physiological aberrations, resulting in a reduced growth. Dale and Fuller (1980) suggested that only $63 \%$ of growth depression in broilers due to heat stress is directly related to reduced feed intake, and concluded that under high temperature, birds try to reduce energy metabolism and protect themselves through starvation (eating less feed to satisfy energy requirement). With the starvation, fewer nutrients are available to the body, which is reflected in the reduction of body weight gain.

The present results of rate of laying are in agreement with Bollengier-Lee et al. (1999) and Mahmoud et al. (1996) who showed that heat stress reduced egg production, and this was due to an imbalance in calciumestrogen relationship. Similarly, Christopher et al. (1995) reported a $32.7 \%$ decrease in laying rate ( 82.9 vs $55.8 \%$ ) in heat-stressed laying hens compared with hens reared under optimal thermal conditions.

The negative effect of CHS on productive performance of laying hens was concurred with a significant decrease in the digestibility coefficient of $\mathrm{CP}$. The reduction on $\mathrm{CP}$ digestibility might be due to the decrease in the activities of trypsin, chymotrypsin and amylase of broiler chickens exposed to $32{ }^{\circ} \mathrm{C}$ that may negatively affect the digestibility of amino acids (Abu-Dieyeh 2006). In addition, Dawoud (1998) indicated that the negative effect of CHS on central nervous system may reduce metabolic rate and feed consumption under CHS. In this regard, plasma glucose concentrations in hens reared CHS decreased which agreements with the depressed body weight gains and other related parameters mentioned above. Glucose is known to be a limiting factor for animal growth.

The decrease in egg production traits of hens exposed to CHS observed herein concurred with a significant decline in ovary weight percentage (11.3\%), large follicle weight (16\%), oviduct weight (25.2\%) and length
(15.6\%). The ovary in poultry displays an essential role in the reproductive functions. Small white follicles (Nitta et al. 1991) produce more than $80 \%$ of the total ovarian estrogen, which controls the reproductive tract growth and development (Campbell et al. 2003). Granulose cells of large ovarian hierarchical follicles in laying hens secreted progesterone, the major steroid hormone (Porter et al. 1991). Disorder of the ovarian function are responsible for reduced reproductive efficiency of hyperthermia hens. In literature, White Leghorn hens exposed to heat stress $\left(42{ }^{\circ} \mathrm{C}\right)$ showed a significant decrease in weight of the ovarian and large follicles number compared to those reared at $24-26{ }^{\circ} \mathrm{C}$ due to the decrease in ovarian blood supply (Rozenboim et al. 2007). The increase in blood supply to the outer skin might be one of the emergent physiological responses that alleviate endogenous thermal load via vasodilatation of the skin, shank, comb and wattle and resulted in inadequate blood supply to the ovary.

Supplementing diet of hens under CHS with VC, VE and Bet partially alleviated the negative effects of the CHS. At the present work, synergetic effect existed between vitamins and Bet, thus these agents may have to be supplied in adequate amount under condition of heat stress as layers can't syntheses adequate amount and animal feedstuffs are poor source of Bet (Wang et al. 2004 Daghir 2008; Attia et al. 2009).

For survival rate, laying rate and feed conversion rate, $\mathrm{VC}$ and Bet were the most effective dietary supplements for revealing the negative effect of CHS on breeder hens, and resulted in complete recovery of feed conversion ratio. The complete recovery in only feed conversion ratio indicated the decrease in maintenance energy requirements. A mixture of Bet with VE showed similar effect but did not do better than Bet or VC alone, implying that Bet or $\mathrm{VC}$ may be an adequate agent in hens exposed to CHS. It should be mentioned that mixture of Bet with VE was more effective than VE alone, which showed less response than Bet and VC. This mixture (Bet with VE) resulted in complete diminishing of the negative effect of CHS on FCR. This synergetic effect may indicate the different mode of action of Bet and VE. The mixture of three agents did not yield further improvement in tolerance to CHS than the single or double supplements. The results also showed that Bet with VC did not show synergetic effect, which implies similar mode of action. In addition, the positive effect of different agents on egg production traits was combined with similar increase in body weight of breeder hens, feed intake and survival rate. For feed intake, Bet was the most effective agent followed by the Bet with $\mathrm{VC}$ or VC with $\mathrm{E}$ mixture, while the least effective agent was Bet with $\mathrm{VE}$ and the mixture of three supplements. 
It is known that feed intake was the most effective factor for egg production (Attia et al. 1995). In addition, egg production, survival rate and feed intake of layers increased due to VC supplementation at 200-400 mg/ kg [Jacob (1995); Çiftçi et al. 2005; Daghir 2008). Laying rate, feed utilization for egg production, weight of egg weight and egg mass significantly increased of layers supplied with 1000 and $1200 \mathrm{ppm} / \mathrm{l}$ water (Ahmed et al. 2008)]. Betaine and VC diet showed similar effects for relief of the negative influence on growth traits of heatstressed chickens (Farooqui et al. 2005; Attia et al. 2009).

$\mathrm{VC}$ is the most effective agent and its positive impact as a water-soluble vitamin can be attributed to its role as a regulator for body temperature and its antioxidant and immune enhancers (Attia et al. 2009). Synthesize of VC is adequate by adult poultry under normal condition although VC supplementation is essential under HS to relief the adverse influence of heat stress (Daghir 2008; Attia et al. 2009).

Bet showed comparable effect to $\mathrm{VC}$ and could replace it as an anti-stress agent without any loss in the productive traits of breeder hens. Furthermore, Bet was more effective than VE and was equal or better than the other combinations of the supplements. Similarly, $0.1 \%$ Bet increased egg production by $10 \%$ through stimulation the secretion in the anterior pituitary of the follicle stimulating hormone and luteinizing hormone (Zou and Feng 2002) and dietary Bet at $0.2 \%$ improved laying rate in heat- stressed layers (Rue et al. 2002). Similarly, very low-density lipoproteins and vitellogenin the precursors of egg yolk were significantly decreased due to heat stress (Bollengier-Lee et al. 1999) and increased by Bet supplementation at $0.06 \%$ (Lu and Zou 2006).

Indeed, fat, protein, methionine, lysine digestibility and carotenoids were enhanced in broilers challenged with coccidiosis and supplemented with Bet compared with chickens challenged and fed Bet unsupplemented diet (Augustine and Danforth 1999). In the present study, Bet improved digestibility of crude protein thus the differences in the PC was eliminated. In addition, VC and $1 \mathrm{~g}$ of Bet $/ \mathrm{kg}$ diet showed similar positive effects for partial relief of the adverse influences of CHS on chickens' performance (Attia et al. 2009). In addition, in vitro study revealed that Bet acts as an osmoprotectant in a range of bacterial groups, such as enterobacteria and lactobacilli, in avoiding dehydration in a hyperosmotic environment (Hutkins et al. 1987).

Corticosterone, catecholamines and lipid peroxidation in cell membrane increased due to exposure to HS, and animal welfare decreased; VE can lower the adverse influences of heat stress on corticosterone secretion (Metwally 2003). VE also protects lymphocytes, macrophages and plasma cells against oxidative damage and increases proliferation and cell' functions, thus enhance the welfare of the animal. Thus, supplementation with VE is essential under condition of heat stress. VE supplementation protects cells and tissues from lipoperoxidative damage induced by free radicals (Bollengier-Lee et al. 1999; Metwally 2003). VE supplementation at $125-250 \mathrm{mg} / \mathrm{kg}$ (Kirunda et al. 2001) and $125 \mathrm{mg} \mathrm{VE}$ plus $200 \mathrm{mg} \mathrm{VC/}$ $\mathrm{kg}$ of diet (Çiftçi et al. 2005) improves laying rate, feed utilization, immunity and deceased the adverse effects of high ambient temperature on productivity of layers. Moreover, VE acts as a physiological synergist and as a functioning portion of specific enzymes (Franchini et al. 1991), and increases yolk precursors, vitellogenin and VLDL during exposure to heat stress, which improves yolk and egg production (Utomo et al. 1994; BollengierLee et al. 1999). Correlation between circulating calcium and oestradiol are positive in laying hens (Tojo and Huston 1980) as oestradiol control 1, 25 dihydroxy cholecalciferol synthesis and the active cholecalciferol metabolite (Taylor and Drake 1984).

Although the synergetic effects of VC, E and/or Bet may enhance laying traits, it received little thoughtfulness deposited through various mode of action. For example, a combination of ascorbate and $\alpha$-tocopherol impaired myoglobin oxidation, whereas $\alpha$-tocopherol or ascorbate alone did not delay metmyoglobin formation (Yin et al. 1993). In addition, VC was found to boost antioxidant activity of VE and guard VE from peroxidation (Jacob 1995; Sahin et al. 2002) by restore the tocopheroxyl radicals to their active form of VE or by sparing available VE (Retsky and Frei 1995). Thus, a positive synergistic influence of $75 \mathrm{IU} / \mathrm{kg}$ of VE and $200 \mathrm{ppm}$ of $\mathrm{VC}$ on the immune function as antibody titer increased of broilers against Brucella abortus and Newcastle modified live and dead virus vaccine was shown (Gonzalez-Vega-Aguire et al. 1995). Also, VE (125 mg/kg diet) plus VC (200 mg/ $\mathrm{kg}$ diet) boosted laying performance in heat-stressed layers (Çiftçi et al. 2005), and VC (150 mg) and/or VE $150 \mathrm{mg}$ improved laying characteristics in layers to heat stress (Ajakaiye et al. 2011). However, VE ( $\alpha$-Tocopherol acetate) did not affect performance of heat-stressed $\left(33^{\circ} \mathrm{C}\right)$ laying hens but increased serum cholesterol and immunity.

\section{Conclusions}

The combined effect of using different antioxidants such synthetic source of $\mathrm{VE}$ at $150 \mathrm{mg} / \mathrm{kg}$ and $\mathrm{C}$ at $200 \mathrm{mg} /$ $\mathrm{kg}$ with Bet at $1000 \mathrm{mg} / \mathrm{kg}$ as a multi-nutritional and osmoregulatory agent in the layer' diets reared under CHS did not excess the influence of any single agent, showing that VC or Bet may be sufficient for enhancing productive traits of dual-purpose breeder hens. 


\section{Abbreviations}

AOAC: Association of official analytical chemists; Bet: betaine; CP: crude protein; CF: crude fiber; CHS: chronic heat stress; DM: dry matter; EE: ether extract; $E_{2}$ : estrogen; FCR: feed conversion ratio; HS: heat stress; NFE: nitrogen free extract; $T_{4}$ : thyroxine; $T_{3}$ : triiodothyronine; $P_{4}$ : progesterone; $V C$ : vitamin $C_{\text {; }}$ VE: vitamin $\mathrm{E}$.

\section{Authors' contributions}

YAA set up the experimental design, carried out the statistical analyses and drafted the manuscript. AEA participated in the laboratory analyses. AAA participated in the design of the study and followed up the field work. MAF followed up the laboratory work. MAA corrected and revised the 1st draft. OK and KS read and revised the final copy. BMA carried out the experimental work and the laboratory analyses. All authors read and approved the final manuscript.

\section{Author details}

${ }^{1}$ Arid Land Agriculture Department, Faculty of Meteorology, Environment and Arid Land Agriculture, King Abdulaziz University, P.O. Box 80208 , Jeddah 21589, Saudi Arabia. ${ }^{2}$ Animal and Poultry Production Department, Faculty of Agriculture, Damanhour University, Damanhour, Egypt. ${ }^{3}$ Department of Poultry Nutrition, Animal Production Research Institute, Ministry of Agriculture and Land Reclamation, Agriculture Research Center, Giza, Egypt. ${ }^{4}$ Department of Animal Nutrition, Faculty of Veterinary Medicine, Erciyes University, Kayseri, Turkey. ${ }^{5}$ Department of Animal Nutrition, Faculty of Veterinary Medicine, Firat University, Elazig, Turkey.

\section{Competing interests}

The authors declare that they have no competing interests.

Received: 2 May 2016 Accepted: 11 September 2016

Published online: 20 September 2016

\section{References}

Abd-Ellah AM (1995) Effect of ascorbic acid supplementation on performance of laying hens during hot summer months. Assiut Vet Med J 34:83-92

Abraham GE (1977) Hand book of Radioimmunoassay. Marcel Dekker, New York Abu-Dieyeh ZHM (2006) Effect of chronic heat stress and long-term feed restriction on broiler performance. Int J Poult Sci 5:185-190

Ahmed W, Ahmad S, Ahsan-Ul-Haq Kamran Z (2008) Response of laying hens to vitamin $C$ supplementation through drinking water under sub-tropical conditions. Avian Biol Res 1:59-63

Ajakaiye JJ, Cuesta-Mazorra M, Garcia-Diaz JR (2011) Vitamins C and E can alleviate adverse effects of heat stress on live weight and some egg quality profiles of layer hens. Pak Vet J 31:45-49

AOAC (2004) Official methods of analysis, 18th edn. Association of official analytical chemists, Washington, DC

Attia YA, Burke WH, Yamani KA, Jensen LS (1995) Energy allotments and performance of broiler breeders. 2-females. Poult Sci 74:261-270

Attia YA, Hassan RA, Shehatta MH, Abd El-Hady SB (2005) Growth, carcass quality and blood serum constituents of slow growth chicks as affected by betaine additions to diets containing 2. Different levels of methionine. Int J Poult Sci 11:856-865

Attia YA, Böhmer Barbara M, Roth-Maier DA (2006) Responses of broiler chicks raised under constant relatively high ambient temperature to enzymes, amino acid supplementations, or diet density. Archiv Geflügelk 70:80-91

Attia YA, Hassan RA, Qota EM (2009) Recovery from adverse effects of heat stress on slow-growing chicks in the tropics 1, effect of ascorbic acid and different levels of betaine. Trop Anim Health Prod 41:807-818

Attia YA, Hassan RA, Tag El-Din AE, Abou-Shehema BM (2011) Effect of ascorbic acid or increasing metabolizable energy level with or without supplementation of some essential amino acids on productive and physiological traits of slow-growing chicks exposed to chronic heat stress. J Anim Phys Anim Nutr 95:744-755

Attia YA, El-Tahawy WS, Abd El-Hamid AE, Hassan SS, Nizza A, EL-Kelway MI (2012) Effect of phytase with or without multienzyme supplementation on juvenile performance and nutrient digestibility of young broiler chicks fed mash or crumble diets. Ital J Anim Sci 11:303-308
Augustine PC, Danforth HD (1999) Influence of betaine and salinomycin on intestinal absorption of methionine and glucose and on the ultrastructure of intestinal cells and parasite developmental stages in chicks infected with Eimeria acervulina. Avian Dis 43:89-865

Ayo JO, Obidi JA, Rekwot PI (2010) Seasonal variations in feed consumption, hen-day, mortality and culls of Bovans Black chickens. In: Proceedings of the 35th annual conference of the Nigerian Society for animal production. University of Ibadan, pp 415-418

Blem CR (2000) Energy balance, in Sturkie's Avian Physiology. In: Whittow GC, editor. 5th ed. Academic Press, pp 327-341

Bollengier-Lee S, Williams PE, Whitehead CC (1999) Optimal dietary concentration of vitamin $E$ for alleviating the effect of heat stress on egg production in laying hens. Br Poult Sci 40:102-107

Campbell JR, Kenealy MD, Campbell KL (2003) Physiology of egg laying. Animal sciences: the biology, care and production of domestic animal, 4th edn. Mcgraw-Hill Higher Educating, New York, pp 283-294

Christopher DM, Bramwell KR, Wilson JL, Howarth B (1995) Fertility of male and female broiler breeders following exposure to elevated ambient temperatures. Poult Sci 74:1029-1038

Çiftci M, Nihat-Ertas O, Guler T (2005) Effects of vitamin E and vitamin C dietary supplementation on egg production and egg quality of laying hens exposed to a chronic heat stress. Veterinarica 156:107-111

Daghir NJ (2008) Poultry production in hot climates, 2nd edn. CAB International, Wallinford, Oxfordshire, p 387

Dale NM, Fuller HL (1980) Effect of diet composition on feed intake and growth of chicks under heat stress. II. Constant vs. cycling temperatures. Poult Sci 59:1434-1441

Dawoud AM (1998) Effect of environmental conditions on body compartments of broilers. Cairo University, Cairo (Ph.D. Thesis)

Dawson WR, Whittow GC (2000) Regulation of body temperature. In: Whitton GC (ed) Avian physiology. Academic Press, New York, pp 343-390

Farooqui HAG, Khan MS, Khan MA, Rabbani M, Pervez K, Khan JA (2005) Evaluation of betaine and vitamin $C$ in alleviation of heat stress in broilers. Int J Agric Biol 5:744-746

Franchini A, Canti M, Manfreda G, Bertuzzi S, Asdrubali G, Franciosi C (1991) Vitamin E as adjuvant in emulsified vaccine for chicks. Poult Sci 70:1709-1715

Franco-Jimenez DJ, Scheideler SE, Kittok RJ, Brown-Brand TM, Robeson LR, Taira $\mathrm{H}$, Beck MM (2007) Differential effects of heat stress in three strains of laying hens. J Appl Poult Res 16:628-634

Gonzalez-Vega-Aguirre D, Conteras BP, Klein R, Bohmwald H (1995) Effect of vitamin $C$ and $E$ supplementation in the diet of broiler chicks on performance and immune response. Veterinarian 26:333-340

Graham H (2002) Betaine-Combating heat stress in poultry. Afma Matrix, pp $16-17$

Hassan RA, Attia YA, El-Ganzory EH (2005) Growth, carcass quality, and blood serum constituents of slow growth chicks as affected by betaine additions to diets containing 1. Different levels of choline. Int J Poult Sci 4:840-850

Hollander CS, Shenkman L (1974) Radiimmunoassay for triiodothyronine and thyroxine. In: Rothfeld B (ed) Nuclear medicine in vitro. Lippincott, Philadelphia, pp 136-149

Hutkins RW, Ellefson WL, Kashket ER (1987) Betaine transport imparts osmotolerance on a strain of Lactobacillus acidophilus. Appl Environ Microbiol 53:2275-2281

Jacob RA (1995) The integrated antioxidant system. Nutr Res 15:755-766

Jakobsen PE, Gertov K, Nielsen SH (1960) Ford Ojelighed sforsogmed fjerkrae. Digestibility trials with poultry 1. Ford Jelseskanolen Hoshons Samt Metodiske Problemer Ved Gennemforelsen Affordojelighedsforsog. 322 Beretning Fra Forsogslaboratorit, Kobenhaven

Khan RU, Naz S, Nikousefat Z, Tufarelli V, Javdani M, Rana N, Laudadio V (2011) Effect of vitamin E in heat-stressed poultry. World's Poult Sci J 67:469-478

Khan RU, Naz S, Nikousefat Z, Selvaggi M, Laudadio V, Tufarelli V (2012a) Effect of ascorbic acid in heat-stressed poultry. World's Poult Sci J 68(3):477-490

Khan RU, Rahman ZU, Nikousefat Z, Javadi M, Tufarelli V, Dario C, Selvaggi M, Laudadio V (2012b) Immunomodulating effects of vitamin E in broilers. World Poult Sci J 68:31-40

Kirunda DFK, Scheideler SE, Mckee S (2001) The efficacy of vitamin E, DI-Alphatocophery acetate supplementation in hen diets to alleviate egg quality deterioration associated with high temperature exposure. Poult Sci 80:1378-1383 
Lu JJ, Zou XT (2006) Effects of adding betaine on laying performance and contents of serum yolk precursors VLDL and VTG in laying hen. J Zheijang Univ Agric Life Sci 32:287-291

Mahmoud KZ, Beck MM, Scheideler SE, Forman MF, Anderson KP, Kachman SD (1996) 0 Acute high environmental temperature and calcium-estrogen relationships in the hen. Poult Sci 75:1555-1562

Metwally MA (2003) Effect of vitamin E on the performance of Dandarawi hens exposed to heat stress. Egypt Poult Sci J 23:115-127

Nitta H, Osawa Y, Bahr JM (1991) Immunolocalisation of steroidogenic cells in small follicles of chicken ovary, anatomical arrangementand location of steroidogenic cells change during follicular development. Domest Anim Endocrinol 32:190-200

Oguntunji OM, Alabi AO (2010) Influence of high environmental temperature on egg production and shell quality, a review. World's Poult Sci J 66:739-774

Panda AK, Ramarao SV, Raju MVLN, Chatterjee RN (2008) Effect of dietary supplementation with vitamins $\mathrm{E}$ and $\mathrm{C}$ on production performance, immune responses and antioxidant status of White Leghorn layers under tropical summer conditions. Br Poult Sci 49:592-599

Porter TE, Hargis BM, Silsby JL, El Halawani ME (1991) Characterization of dissimilar steroid production by granulosa, theca internal and theca external cells during follicular maturation in the turkey, Meleagris gallopavo. Gen Comp Endocrinol 84:1-8

Retsky KL, Frei B (1995) Vitamin C prevents metal ion dependent initiation and propagation of lipid peroxidation in human low-density lipoprotein. Biochim Biophys Acta 125:279-287

Rozenboim I, Tako E, Gal-Garber O, Proudman JA, Uni Z (2007) The effect of heat stress on ovarian function of laying hens. Poult Sci 86:1760-1765

Rue MS, Cho KH, Shin WJ, Ryu KS (2002) Influence of dietary supplemental betaine on performance and egg quality of laying hens during the heat stress. Korean J Poult Sci 29:117-123

Sahin K, Sahin N, Yaralioglu S (2002) Effects of vitamin C and vitamin E on lipid peroxidation, blood serum metabolites, and mineral concentrations of laying hens reared at high ambient temperature. Biol Trace Elem Res 85:35-45

SAS Institute (1996) SAS user's guide. Version 6.12. SAS Institute Cary, New York

Smith OM (1994) Effect of electrolytes and lighting regime on growth of heat distressed broilers. Poult Sci 73:350-353
Taylor TG, Drake CG (1984) Calcium metabolism and its regulation. In: Freeman BM (ed) Physiology and biochemistry of the domestic fowl, vol 5. Academic press, London, pp 125-170

Tojo H, Huston TM (1980) Effects of environmental temperature on the concentration of serum ostradiol, progesterone, and calcium in maturing female domestic fowl. Poult Sci 59:2797-2802

Traber MG, Atkinson J (2007) Vitamin E, antioxidant and nothing more. Free Radical Biol Med 43:4-15

Trinder P (1969) Determination of glucose in blood using glucose oxidase with an alternative oxygen receptor. Ann Clin Biochem 6:24-27

Tumová E, Gous RM (2012) Interaction of hen production type, age, and temperature on laying pattern and egg quality. Poult Sci 91:1269-1275

Türker M, Alp M, Kocabacli N (2004) Performance of broiler chicks fed on reduced methionine diets supplemented with betaine. XXII Poultry Congress, Istanbul, pp 8-13

Uni Z, Gal-Garger O, Geyra A, Sklan D, Yahav S (2001) Changes in growth and function of chick small intestine epithelium duo to early thermal conditioning. Poult Sci 80:438-445

Utomo DB, Mitchell MA, Whitehead CC (1994) Effects of alpha tocopherol supplementation on plasma egg yolk precursor concentrations in laying hens exposed to heat stress. Br Poult Sci 35:828-829

Wang YZ, Xu ZR, Feng G (2004) The effect of betaine and DL- methionine on growth performance and carcass characteristics in meat ducks. Anim Feed Sci Technol 116:151-159

Yahav S, Goldfeld S, Plavnik I, Hurwitz S (1995) Physiological response of chickens and turkey to relative humidity during exposure to high ambient temperature. J Therm Biol 20:245-253

Yin MC, Faustman C, Riesen JW, Williams SN (1993) Alpha-tocopherol and ascorbate delay oxymyoglobin and phospholipid oxidation in vitro. J Food Sci 58:1273-1276

Yousef MK (1985) Stress physiology in Livestock. Volume III. Poultry. CRC Press, Boca Raton, pp 130-134

Zou XT, Feng J (2002) Effect of betaine on performance of laying hens. Chin J Anim Sci 38:7-9

\section{Submit your manuscript to a SpringerOpen ${ }^{\circ}$ journal and benefit from:}

- Convenient online submission

- Rigorous peer review

- Immediate publication on acceptance

- Open access: articles freely available online

- High visibility within the field

- Retaining the copyright to your article

Submit your next manuscript at springeropen.com 